\title{
DIVERSITY AND DISTRIBUTION OF PLASMODIAL MYXOMYCETES (SLIME MOLDS) FROM LA MESA ECOPARK, QUEZON CITY, PHILIPPINES
}

\author{
SITTIE AISHA B. MACABAGO ${ }^{1}$, NIKKI HEHERSON A. DAGAMAC ${ }^{1}$ \\ and THOMAS EDISON E. DELA CRUZ ${ }^{1,2}$ \\ ${ }^{1}$ The Graduate School, University of Santo Tomas \\ ${ }^{2}$ Fungal Biodiversity and Systematics Group, Research Center for the Natural Sciences \\ University of Santo Tomas \\ España 1015 Manila, Philippines
}

Received 04 August 2010 / Accepted 12 October 2010

\begin{abstract}
ABSRACT
Myxomycetes are ubiquitous in terrestrial forest ecosystems. Thus, this research study looks at the taxonomic diversity and distribution of plasmodial myxomycetes in La Mesa Ecopark in Quezon City, Philippines. A total of 240 moist chambers were prepared from four substrates (aerial and ground leaf litter, twigs and barks) collected within this ecopark. Following incubation of moist chambers for eight weeks, a total of 28 species belonging to 10 genera were collected and identified: Arcyria (3), Diderma (2), Didymium (5), Lamproderma (2), Perichaena (3), Physarum (8), Macbrideola (1), Metatrichia (1), Trichia (1) and Stemonitis (2). Highest myxomycete yield $(85 \%)$ was observed in aerial leaf litter. In terms of taxonomic diversity, highest diversity was observed in bark microhabitats, although the lowest number of species was recorded in it. Assessment of their abundance and distribution showed similarities in species composition between aerial and ground leaf litter. This research study is the first report of plasmodial myxomycetes in La Mesa Ecopark in Quezon City, Philippines.
\end{abstract}

Keyword: Myxomycetes, slime molds, microhabitats, recreational forest

\section{INTRODUCTION}

Myxomycetes are morphologically diverse group of fungus-like, eukaryotic protists with approximately 985 species described worldwide (Lado 2003). Majority of the described species are of cosmopolitan distribution, though a few species appear to be confined in the tropics or subtropics while some have been collected only in the temperate regions of the world (Alexopoulos 1963; Farr 1976; Martin et al. 1983). In

$\overline{\text { *Corresponding author: sittieaisha@gmail.com/tedelacruz@mnl.ust.edu.ph }}$ 
spite of their worldwide distribution, limited studies have been done on these organisms in the Philippines. Uyenco (1973) identified only 18 species belonging to 10 genera from specimens collected in Quezon City in Metro Manila and in the provinces of Laguna, Basilan and Zamboanga during 1961 to 1973. Dogma (1975) listed 46 species from 20 genera and included 22 species previously credited to the Philippines by Martin and Alexopoulos (1969) in their book "The Myxomycetes." But perhaps, the most extensive works on Philippine myxomycetes was the annotated list of Reynolds (1981). He reported in this annotated list the myxomycete collections from Davao, Cotabato and Zamboanga by E. B. Copeland, from Benguet by A. D. E. Elmer, and from Bataan, Manila, Cavite and Laguna by E.D. Merrill. Included also in the list were Reynolds's myxomycete collection from the Philippines and that of other Filipino mycologists of his time. In this report, a total of 107 species of myxomycetes have been recorded so far for the Philippines, 53 were new records for the country (Reynolds 1981). But since then, studies on Philippine myxomycetes remained stagnant. Only just recently that interest in these organisms came about. Dagamac et al. (2010) reported seven corticolous myxomycetes from different sites in Luzon, five were new records for the country. Dagamac (2010) also assessed the myxomycete diversity on Mt. Arayat National Park, Pampanga and reported a total of 34 species, 5 of these were new records for the Philippines. One species, Craterium retisporum G. Moreno, D.W. Mitch. And S.L. Stephenson, was also reported new to science from a specimen collected in Anda Island, Pangasinan (Moreno et al. 2009). However, the number is still considered small as compared to recent studies on myxomycetes in Southeast Asia (Tran et al. 2006). Thus, many more myxomycetes species can still be found in many of the remaining unexplored areas of the country. Located in Quezon City, Metro Manila, the La Mesa Ecopark is one of the remaining forested areas in the metropolis and provides a venue for many outdoor recreational activities. It also serves as a living classroom and laboratory for environmental education and thus, is an ideal site to study biodiversity and conservation. However, no studies on myxomycetes have ever been reported from this location. Thus, this research study assesses the occurrence and distribution of plasmodial myxomycetes within the forested areas of La Mesa Ecopark. As a baseline study, this may signal future researches to foster the need for biodiversity assessment in leisure parks.

\section{MATERIALS AND METHODS}

\section{Collection site}

The La Mesa Ecopark (N 14 42'48.4”, E 14 42'48.4”, elevation: 71 meter above sea level) lies approximately $10 \mathrm{~km}$ northeast of Metro Manila (Fig. 1). The forest areas within the ecopark are dominated by dipterocarp trees, e.g., mahogany trees (Swietenia macrophylla King.). It is also characterized by two distinct seasons: dry from November to May and wet from June to October. Within this conserved leisure area, 16 sites were randomly selected for the collection of different microhabitats: aerial and ground leaf litter, twigs, and barks. 


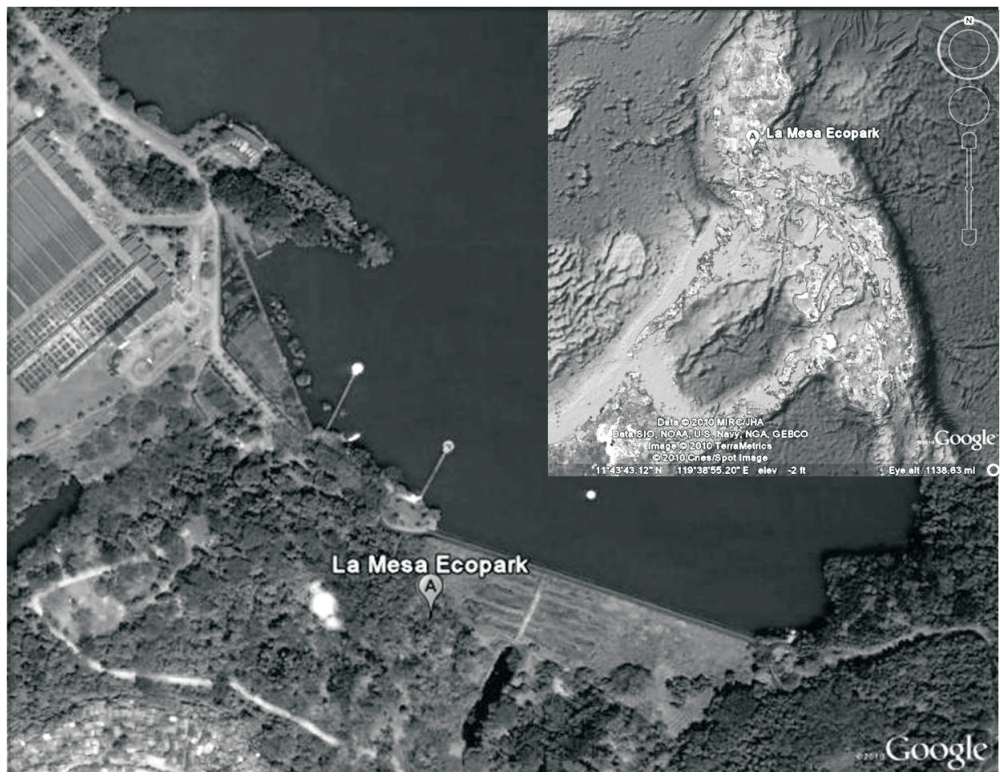

Figure 1. The study site: La Mesa Ecopark situated within the La Mesa Watershed in Quezon City, Philippines (Map Source: GoogleEarth).

\section{Collection of substrates and preparation of moist chamber}

Twenty samples each of aerial leaf litter (AL), ground leaf litter (GL), barks of living trees (BK), and twigs (TW) were randomly collected in the month of August 2008. The collected substrates (80) were then placed inside dry paper bags, labeled properly and then transported to the laboratory. The substrates were initially air-dried prior to the preparation of moist chambers (MC). Moist chambers (240) were then prepared for each of the collected samples as described by Stephenson and Stempen (1994). The use of moist chamber in assessing the diversity of myxomycetes had been demonstrated in several studies (Harkonen 1981; Lado et al. 2003; de Basanta et al. 2008; Kilgore et al. 2009) and is sufficient to reflect the diversity of myxomycetes in a particular habitat or study site (Novozhilov et al. 2000). To prepare the moist chamber (MC), all leaf litter and bark samples were initially cut into postage stamp-sized pieces. Twigs were cut into 2-3 inches length. Then, ten pieces leaf litter (per plate) and five pieces of twig and bark samples (per plate) were placed in disposable Petri dishes lined with filter paper ( 3 plates per sample). The set-ups were then soaked overnight in sterile distilled water. After 24 hours, excess water was poured out from the samples. The moist chamber set-up was maintained under diffuse light at room temperature $\left(22-25^{\circ} \mathrm{C}\right)$ for up to 8 weeks ( 2 months). Moist chambers were checked every week for the presence of myxomycete plasmodia and/or fruiting bodies. If the moist chambers dried up for the first time and no myxomycetes were observed, water was added to keep the culture moist and were further incubated until the $8^{\text {th }}$ week. If no fruiting bodies and/or plasmodia develop, then, it was considered as negative for myxomycete 
growth. Only those Petri dishes that yielded fruiting body and/or plasmodial growth were noted as a single positive collection for myxomycetes.

\section{Characterization and identification of plasmodial myxomycetes}

Fruiting bodies of plasmodial myxomycetes were initially air-dried and placed on separate herbarium boxes. All herbaria were deposited at the Pure and Applied Microbiology Laboratory, Research Center for the Natural Sciences, University of Santo Tomas in Manila, Philippines. Photographs of each of the specimens were also taken using Moticam 1000 (Motic USA). To identify the myxomycetes, the specimens for each species were described based on their fruiting body characteristics and spore morphology. For the fruiting body characteristics, the specimens were observed under a dissecting microscope and the following characters were noted: type, size, shape, appearance and color of fruiting bodies, appearance of internal structures, e.g., capillitium, and the presence or absence of lime $\left(\mathrm{CaCO}_{3}\right)$. For the spore morphology, spores from the fruiting bodies were mounted on a slide with lactophenol and the slide was viewed under a light compound microscope (Olympus USA). Spore shape, texture and color were then noted for each specimen. Following fruiting body and spore morphology characterization, the specimens were then identified using published literatures (Stephenson \& Stempen 1994; Keller \& Braun 1999) and webbased identification key (http://slimemold.uark.edu/). Names were based on the online nomenclatural database for eumycetozoan (http://nomen.eumycetozoa.com).

\section{Assessment of Myxomycete Diversity}

Statistical and ecological analyses were conducted to analyze the diversity and distribution of myxomycete assemblages in La Mesa Ecopark.

\section{Percent Yield}

To have an overview of the distribution of myxomycetes in the study site, the percent yield was first computed for each substrate type. A moist chamber that exhibited either plasmodial and/or fruiting body growth was considered here as positive for myxomycetes, and thus, was noted as one positive collection. The number of positive collections was then counted and divided by the total number of $\mathrm{MC}$ prepared. Thus, the percent yield (PY) was computed as follows:

Percent Yield $(\mathrm{PY})=\frac{\text { number of MC positive for myxomycetes }}{\text { total number of MC prepared }} \times 100 \%$

\section{Species Composition and Occurrence}

The species composition was initially determined for the collection site. This is simply an enumeration or listing of myxomycetes collected from the study area. Then, the occurrence of each myxomycete species in each substrate type was determined. Occurrence refers to the frequency of the presence of a particular species of myxomycetes in a positive MC. Take note that a moist chamber positive for a fruiting 
body of a particular species is considered as one positive collection. A collection now is then considered as an individual unit. The number of collections reflects how abundant the myxomycetes in La Mesa Ecopark and was expressed as relative abundance (RA).

$$
\mathrm{RA}=\frac{\text { number of collection for a specific myxomycetes }}{\text { total number of myxomycete collections }} \times 100 \%
$$

The relative abundance for every species of myxomycetes was then translated and reported as Abundance Index (AI). The AI was determined by assigning a "breaking point" based on their relative abundance (S. L. Stephenson, pers. comm., 04 January 2009). Each species were then categorized as: (1) abundant (A) if their relative abundance is $\geq 10 \%$ of the total collections, (2) common (C) if RA is $\geq 5 \%$ but $<10 \%$ of the total collections, (3) occasionally occurring (O) if RA is $\geq 3$ but $\leq 5 \%$ of the total collections, and (4) rare (R) if the myxomycetes had an RA of $<3 \%$ of the total collections.

\section{Taxonomic Diversity}

Initially, the number of species and genera for each substrate type was counted. The taxonomic diversity was then computed by getting the ratio of the number of species with the number of genera ( $\mathrm{S} / \mathrm{G}$ ratio). A value for the $S / G$ ratio is inversely proportional to its taxonomic diversity, thus, the lower the $S / G$ ratio, the more diverse a particular biota is considered. Stephenson et al. (1993) noted that a biota in which the species are divided among many genera is "intuitively" more diverse in a taxonomic sense than one in which most species belong to only a few genera.

$$
\mathrm{S} / \mathrm{G} \text { Ratio }=\frac{\text { number of species }}{\text { number of genera }}
$$

\section{RESULTS AND DISCUSSIONS}

\section{Percent yield}

Following incubation of the four microhabitats (AL, GL, BK and TW) for 8 weeks, our results showed that $51 \%$ or 122 of the 240 prepared MC yielded either plasmodial growth or fruiting bodies of myxomycetes. Among the four microhabitats, aerial leaf litter showed the highest myxomycete yield ( $85 \%$ ) followed by twigs (48\%), ground leaf litter (43\%), and barks (27\%) (Fig. 2). These differences can be attributed, at least in part, to the distinction in physical characteristics of the substrates, e.g., the presence of coarse woody debris or a leaf with a rough or pubescent surface would appear to have a higher potential for trapping myxomycete spores from the air than a leaf with a smooth surface (Stephenson 1989). It was, however, reported that barks of living trees in temperate forests had greater yield (90\%) of myxomycetes than leaf litter $(70 \%)$ using the moist chamber technique. This contrasted with our research findings wherein leaf litter (85\%) yielded more myxomycetes than bark $(27 \%)$ substrates (Fig. 2). This is not surprising perhaps due to the ecological differences 
between the study sites, i.e. our sites being in the tropics while their study was conducted in a temperate country. Schnittler and Stephenson (2000) also concluded that litter-inhabiting myxomycetes reached their maximum diversity in the tropical moist forest.

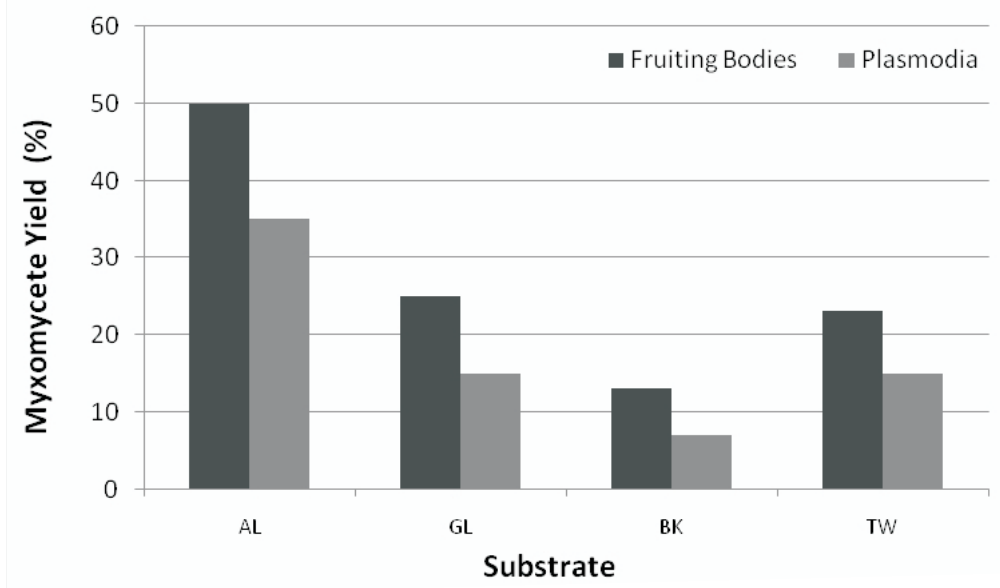

Figure 2. Percent yield of myxomycetes on the four microhabitats collected from La Mesa Ecopark, Quezon City, Philippines: AL (aerial leaf litter), GL (ground leaf litter), BK (barks of living trees) and TW (twigs).

\section{Occurrence and taxonomic diversity}

Morphological characterization of the collected myxomycetes identified 28 species of myxomycetes belonging to 10 genera: Arcyria cinerea (Bull.) Pers., A. denudata (L.) Wettst., Arcyria sp., Diderma effusum (Schwein.) Morgan, D. hemisphaericum (Bull.) Hornem., Didymium nigripes (Link) Fr., D. squamulosum (Alb. \& Schwein.) Fr., Didymium sp1., Didymium sp2., Didymium sp3., Lamproderma scintillans (Berk. \& Broome) Morgan, Lamproderma sp., Perichaena chrysosperma (Curr.) Lister, P. corticalis (Batsch) Rostaf., $P$. depressa Lib., Physarum cinereum (Batsch) Pers., P. compressum Alb. \& Schwein, P. globuliferum (Bull.) Pers., Physarum sp1., Physarum sp2., Physarum sp3., Physarum sp4., Physarum sp5., Macbrideola sp., Metatrichia vesparia (Batsch) Nann.-Bremek. ex G.W. Martin \& Alexop., Trichia botrytis (J.F. Gmel.) Pers., Stemonitis sp1., and Stemonitis sp2. (Table 1, Fig. 3). Among the 28 species of myxomycetes collected, Arcyria cinerea was mostly collected, i.e. 74 collections from the four substrates, while some species from the genera Didymium, Diderma, Perichaena and Physarum were commonly occurring on leaf litter substrates. Most species were collected at different frequencies in either one of the substrates (Table 2). Among the substrates used, aerial leaf litter had the most number of collections of myxomycetes. This was followed by ground leaf litter, twigs, and then, bark. The highest number of species was also recorded from leaf litter. This suggested that leaf litter served as favorable substrates for the growth of most myxomycete species. Note that leaf litter also gave the highest percent myxomycete 
yield (Fig. 2). On the contrary, although moist chambers prepared from ground and leaf litter showed more evidences of myxomycetes in a study in Costa Rica, i.e. $92 \%$ of the MC showed plasmodia and/or fruiting bodies, 34\% of all the specimens collected were from twigs and bark substrates. This is interesting since only $20 \%$ of all substrates collected were twigs and barks, and thus, were more productive (Rojas \& Stephenson 2008). Furthermore, it was reported that twigs were the substrate characterized by the highest mean number of fruiting bodies per moist chamber culture (Rojas \& Stephenson 2008). The reasons, however, for these substrate specificities among myxomycetes were not yet known (Eliasson 1981; Blackwell 1984), but perhaps the physico-chemical nature of these substrates play an important role. For example, differences in the rate of decomposition of substrates represented a factor that needs to be considered in myxomycete diversity studies, with thin and soft leaves decaying much faster than their thicker and harder counterparts (Tran et al. 2006). Decomposing material provides a more suitable microhabitat for myxomycetes due to the presence of more available food microorganisms, e.g. bacteria, yeasts, fungal spores, etc.

However, when taxonomic diversity is considered, i.e. in terms of the species/genus ratio, with only four species belonging to three genera, bark was the most taxonomically diverse (Table 1). Stephenson et al. (1993) noted that a biota in which the species are divided among many genera is "intuitively" more diverse in a taxonomic sense than one in which most species belong to only a few genera. Thus, the lower $\mathrm{S} / \mathrm{G}$ ratio value $(\mathrm{S} / \mathrm{G}$ ratio for bark samples is 1.33 ), the higher the taxonomic diversity. The taxonomic diversity was determined in this research study since its measurement caters to the evolutionary differences in the genus level than between species collected in a particular area. Surprisingly, the lowest taxonomic diversity was noted both from aerial and ground leaf litter ( $\mathrm{S} / \mathrm{G}$ ratio for both leaf litter is 2.00), although 12 species of myxomycetes belonging to 6 genera were collected from this substrate. This contrasted with the fact that many myxomycetes were observed from this substrate. Though many MC with aerial leaf litter as substrate yielded myxomycetes (Table 1), species commonly encountered included only two species of Didymium (Table 2). It is also interesting to note that some species of myxomycetes almost always occur on either twigs or barks, e.g. two species of Stemonitis were found only in twigs, though it occurs rarely. Although associations are not absolute between the myxomycetes and their respective substrates, they are much too frequent to be attributed to chance alone (Eliasson 1981; Blackwell 1984). Furthermore, the patterns of distribution of myxomycetes in relation to the substrates to which they occur were studied (Stephenson et al. 1993). Most of the myxomycetes occurring in the temperate

Table 1. Taxonomic diversity (S/G ratio) of myxomycetes collected from the four substrates in La Mesa Ecopark, Quezon City.

\begin{tabular}{cccccc}
\hline & AL & GL & BK & TW & Total \\
\hline No. of species & 12 & 12 & 4 & 10 & 28 \\
No. of genera & 6 & 6 & 3 & 6 & 10 \\
S/G value & 2.00 & 2.00 & 1.33 & 1.67 & 2.80 \\
\hline
\end{tabular}

Note : Substrates: aerial leaf litter (AL), ground leaf litter (GL), barks (BK), twigs (TW) 


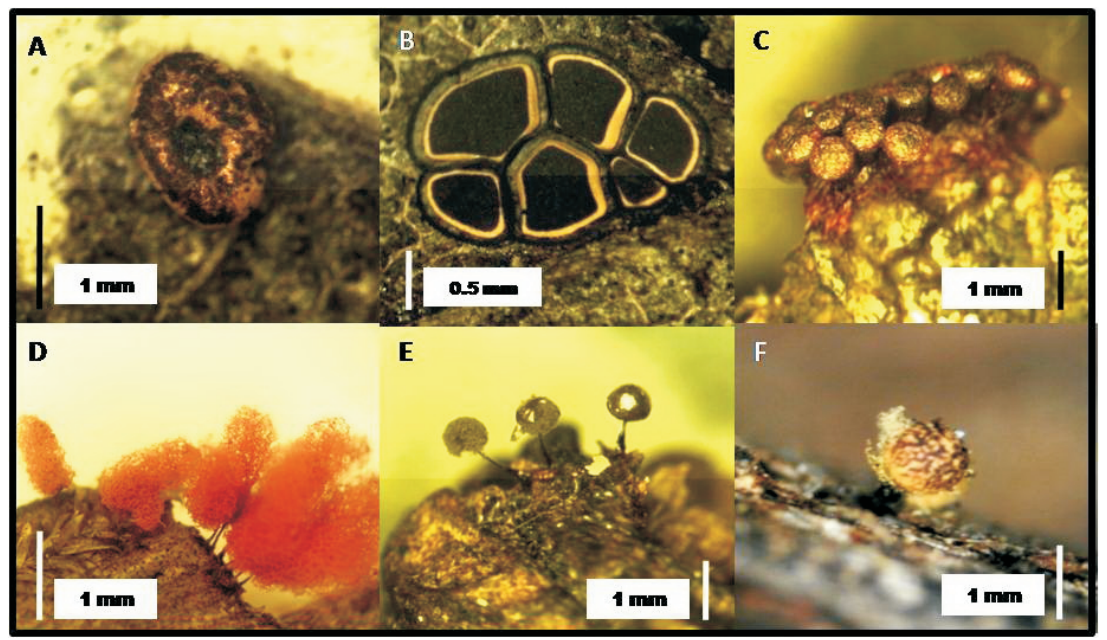

Figure 3. Representative species of myxomycetes collected and identified from La Mesa Ecopark, Quezon City, Philippines: (A) P. chrysosperma, (B) P. depressa, (C) M. vesparia, (D) A.denudata, (E) L. scintillans, and (F) T. botrytis.

Table 2. Distribution and abundance of myxomycetes from La Mesa Ecopark, Quezon City ${ }^{2}$.

\begin{tabular}{lccccc}
\hline \multicolumn{1}{c}{ Taxon } & Aerial Litter & Ground Litter & Barks & Twigs & No. of Collections \\
\hline Arcyria cinerea & $\mathrm{A}$ & $\mathrm{A}$ & $\mathrm{A}$ & $\mathrm{A}$ & 74 \\
Arcyria denudata & - & - & $\mathrm{R}$ & - & 1 \\
Arcyria sp. & - & - & - & $\mathrm{R}$ & 1 \\
Didymium nigripes & $\mathrm{R}$ & $\mathrm{R}$ & - & - & 2 \\
Didymium squamulosum & $\mathrm{R}$ & $\mathrm{A}$ & - & - & 6 \\
Didymium sp1. & $\mathrm{C}$ & - & - & - & 2 \\
Didymium sp2. & - & $\mathrm{R}$ & - & - & 1 \\
Didymium sp3. & $\mathrm{C}$ & - & - & - & 2 \\
Diderma effusum & $\mathrm{A}$ & $\mathrm{C}$ & - & - & 12 \\
Diderma bemisphaericum & $\mathrm{A}$ & $\mathrm{C}$ & - & - & 5 \\
Perichaena chrysosperma & $\mathrm{R}$ & - & - & - & 1 \\
Perichaena corticalis & - & $\mathrm{R}$ & - & - & 1 \\
Perichaena depressa & - & $\mathrm{C}$ & $\mathrm{C}$ & $\mathrm{R}$ & 5 \\
Physarum cinereum & - & - & - & $\mathrm{R}$ & 1 \\
Physarum compressum & - & $\mathrm{C}$ & - & - & 2 \\
Physarum globuliferum & $\mathrm{R}$ & - & - & - & 1 \\
Physarum sp1. & - & $\mathrm{R}$ & - & - & 1 \\
Physarum sp2. & $\mathrm{R}$ & - & - & - & 1 \\
Physarum sp3. & $\mathrm{R}$ & - & - & - & 1 \\
Physarum sp4. & - & - & - & $\mathrm{R}$ & 1 \\
Physarum sp5. & - & $\mathrm{R}$ & - & $\mathrm{C}$ & 4 \\
Macbrideola sp. & - & - & - & - & 1 \\
Metatrichia vesparia & - & - & $\mathrm{R}$ & - & 1 \\
Trichia botrytis & - & - & - & $\mathrm{R}$ & 1 \\
Stemonitis sp1. & - & - & - & $\mathrm{R}$ & 1 \\
Stemonitis sp2. & - & - & - & $\mathrm{R}$ & 1 \\
Lamproderma sp. & Lamproderma scintilans & - & - & $\mathrm{R}$ & 1 \\
\hline Note: A & - & - & & \\
\hline
\end{tabular}

Note: Abundant (A) : $10 \%$ of the total collections

Common $(\mathrm{C}) \quad: \quad 5 \%$ but $<10 \%$ of the total collections

Occasional $(\mathrm{O}) \quad: \quad 3$ but $<5$ of the total collections

Rare (R) : $3 \%$ of the total collections 
regions seem to be lignicolous since $>70 \%$ of all the collections were from wood in the northern part. However, only $26 \%$ of all the collections in the southern part occurred on wood, majority of which were from litter. This certainly suggests that the species of myxomycetes in tropical/sub-tropical regions of the world exhibit quite different patterns of distribution with respect to the substrate to which they typically occur (Stephenson et al. 1993). In addition, most myxomycetes occurring on woody substrates, i.e. on barks and twigs, belong to the taxonomic Orders Stemonitales and Trichiales (Stephenson et al. 1993). Most species occurring on litter belong to Physarales. In this study, a similar pattern was noted (Table 2). Since most of the collections in leaf litter belong to many species from relatively few genera in the order Physarales, and most of the collections in woody substrates belong to only a few species in the orders Trichiales and Stemonitales, the woody substrates would record a lower value for $S / G$ ratio and therefore, a higher taxonomic diversity. Although occurrence and distribution of myxomycetes may be varying according to regions, one factor about differences in diversity may be well accounted for. The ability of a myxomycete plasmodium to migrate some distance from the substrate within which it developed has the potential of obscuring substrate relationships (Stephenson et al. 1993). It has been suggested that the plasmodia of species in Physarales may be somewhat less hydrophilic than those of the other myxomycetes (Venkataramani \& Kalyanasundaram 1986). As such, the larger number of collection of a wide variety of species of Physarales in litter may be well attributed to this fact: woody debris tend to accumulate more moisture than the thin sheets of leaves in a moist chamber. In addition, some myxomycetes may fail to produce fruiting bodies. This affects the assessment of diversity. Stephenson (1989) reported that $90 \%$ of the MC prepared with bark samples produced some evidence of myxomycetes, including plasmodia that failed to produce fruiting bodies.

\section{Distribution and abundance of myxomycetes}

The distribution of myxomycetes within the ecopark was also assessed (Table 2). Four species were found abundant in one or more of the collected substrates in La Mesa Ecopark: Arcyria cinerea, Diderma effusum, Didymium squamulosum and Diderma hemisphaericum. Seven species (i.e., Didymium sp1., Didymium sp3., D. effusum, D. hemisphaericum, Perichaena depressa, Physarum compressum and Physarum sp5.) were also recorded as common in one or two of the substrate types. The relative abundance of each species of myxomycetes for each substrate type was also determined. Among the collected species, Arcyria cinerea was the most abundant and was observed in all four substrates. This was not surprising because $A$. cinerea has a cosmopolitan distribution. This species was found to be exceedingly common and appeared in $43 \%$ of the MC cultures from both bark and litter substrates (Stephenson 1989). Differences in myxomycete abundance were also noted among the four substrates. Four species were found mostly abundant in aerial and ground leaf litter while the least number of myxomycetes were observed in barks (Table 2). In general, members of the Physarales tend to be more commonly associated with litter than is the case for members of the other orders of myxomycetes (Martin \& Alexopoulus 1969). This is similarly observed 
in this research study. Most members of the orders Stemonitales ad Trichiales were almost always collected in woody debris in north-western India (Stephenson et al. 1993). Not a single member of Trichiales was ever collected from litter in the study. In contrast, members of Stemonitales and Trichiales in Southern India were well represented on litter. In La Mesa Ecopark, however, most of the Stemonitales and Trichiales species were found on woody substrates- bark and twigs. It is possible that the relative abundance of the two major substrate types and differences relating to their basic nature may have contributed to the differences observed (Stephenson $e t$ al. 1993). We also observed some species of myxomycetes unique or recorded only in one microhabitat: Macbrideola sp1. in AL, Lamproderma sp1. in GL, Metarichia vesparium and Trichia botrytis in BK, and Lamproderma scintillans and Physarum cinereum and Physarum sp4. in TW. Majority of the myxomycete species found in La Mesa Ecopark are rarely occurring. Some species, like D. effusum, D. hemisphaericum and D. squamulosum, were abundant only in aerial or ground leaf litter. Myxomyces are among the most widely distributed of all terrestrial organisms (Stephenson et al. 1993). The possibility, however, of endemism or spatial distribution is great due to the differences in occurrence patterns shown in various regions of the world. In this study, it was shown that, evidently, myxomycetes are not found with equal abundance on all of the substrates available to them.

\section{CONCLUSIONS}

A total of 28 myxomycete species belonging to 10 genera were collected and identified in La Mesa Ecopark in Quezon City, Philippines: Arcyria cinerea, A. denudata, Arcyria sp., Diderma effusum, D. hemisphaericum, Didymium nigripes, D. squamulosum, Didymium sp1., Didymium sp2., Didymium sp3., Lamproderma scintillans, Lamproderma sp., Perichaena chrysosperma, $P$. corticalis, $P$. depressa, Physarum cinereum, $P$. compressum, $P$. globuliferum, Physarum sp1., Physarum sp2., Physarum sp3., Physarum sp4., Physarum sp5., Macbrideola sp., Metatrichia vesparia, Trichia botrytis, Stemonitis sp1., and Stemonitis sp2. From the moist chambers prepared, 51\% produced positive growth in all the four substrates- highest of which was from aerial litter, followed by twigs and ground litter, and by barks. On the contrary, the highest taxonomic diversity was computed for barks, followed by twigs, ground leaf litter, and aerial leaf litter. Evaluation of their distribution and abundance showed four species to be most abundant or commonly occurring. Most species were recorded as rare in one or more substrates.

\section{REFERENCES}

Alexopoulos C. 1963. The Myxomycetes II. The Botanical Review, 29 (1): 1-78.

Blackwell M. 1984. Myxomycetes and their arthropod associates. Fungus-insect relationships: perspectives in ecology and evolution (edited by Q. D. Wheeler and M. Blackwell). p. 67-90. Columbia University Press, New York.

Dagamac N.H.A., Leontyev D. and T.E.E. dela Cruz. 2010. Corticolous myxomycetes associated with Samanea saman collected from different sites in Luzon Island, Philippines. Philippine BIOTA (in press). 
Dagamac N.H.A. 2010. Myxomycetes along the two trails of Mt. Arayat National Park: Diversity, Distribution and the Development of an Interactive database (M. Sc. thesis). University of Santo Tomas, Manila, Philippines.

de Basanta D., Stephenson S. Lado, C. EstradaTorres A. and A. Nieves-Rivera. 2008. Lianas as a microhabitat for myxomycetes in tropical rainforests. Fungal Diversity, 28: 109125.

Dogma I.J. 1975. Of Philippine mycology and lower fungi. Philipine Journal of Biology, 4: 69-105.

Eliasson U. 1981. Patterns of occurrence of myxomycetes in a spruce forest in South Sweden. Holarctic Ecology, 4:20-31.

Farr M.L. 1976. Flora Neotropica. New York Botanical Garden (Monograph 16), New York.

Harkonen M. 1981. Gambian Myxomycetes developed on moist chamber cultures. Karstenia, 21:21- 25.

Keller H.W. and K.L Braun. 1999. Myxomycetes of Ohio: Their Systematics, Biology and Use in Teaching. Ohio Biological Survey Vol 13. No. 2. Columbus, Ohio, USA.

Kilgore C.M., Keller H.W. and J.S. Ely. 2009. Aerial reproductive parts of vascular plants as a microhabitat for myxomycetes. Mycologia, 101(3): 305-319.

Lado C., Estrada-Torres A., Stephenson S.L., Wrigley-de Basanta D. and M. Schnittler. 2003. Biodiversity assessment of myxomycetes from two tropical forest reserves in Mexico. Fungal Diversity, 12:67-110.

Martin G.W., Alexopoulos C.J. and M.L Farr. 1983. The genera of Myxomycetes. University of Iowa Press, Iowa City.

Martin G.W. and C.J. Alexopoulos. 1969. The Myxomycetes. University of Iowa Press, Iowa City.

Moreno G., Mitchell D.W., Stephenson S.L. and T.E. dela Cruz. 2009. A new species of Craterium (Myxomycetes) with reticulate spores. Boletín de la Sociedad Micológica de Madrid, 33: 175-180.

Novozhilov Y.K., Schnittler M., Zemlianskaia IV. and K.A. Fefelov. 2000. Biodiversity of plasmodial slime molds (Myxogastria): Measurement and interpretation. Protistology, 1 (4):161-178.

Reynolds D.R. 1981. Southeast Asian myxomycetes II. Philippine Journal of Biology, 10 (2-3): 127-150.

Rojas L. and S.L. Stephenson. 2008. Myxomycete ecology along an elevation gradient on Cocos Island, Costa Rica. Fungal Diversity, 29: 117-127.

Schnittler M. and S.L. Stephenson. 2000. Myxomycete biodiversity in four different forest types of Costa Rica. Mycologia, 92(4): 626-637.

Stephenson S.L. 2003. Myxomycetes associated with decaying fronds of nikau palm (Rhopalostylis sapida) in New Zealand. New Zealand Journal of Botany, 41:311-317.

Stephenson S.L. and H. Stempen. 1994. Myxomycetes: A Handbook of Slime Molds. Timber Press, Inc., USA.

Stephenson S.L., Kalyanasundaram I. and T.N. Akhanpal. 1993. A comparative biogeographical study of myxomycetes in the mid-Appalachians of eastern North America and two regions of India. Journal of Biogeography, 20: 645-657.

Stephenson S.L. 1989. Diversity and ecology of myxomycetes in temperate forests. II. Patterns of occurrence on bark surface of living trees, leaf litter, and dung. Mycologia, 81(4): 608- 621.

Tran H., Stephenson S., Hyde K. and O. Mongkolporn. 2006. Distribution and occurrence of myxomycetes in tropical forests of northern Thailand. Fungal Diversity, 22: 227-242.

Uyenco F.R. 1973. Myxomycetes of the Philippines. U.P. National Science Research Centre Technical report. 12: $1-23$.

Venkataramani R. and I. Kalyanasundaram. 1986. Distribution and ecology of myxomycetes in India. Proceedings Indian Academy of Sciences, 96:289-301. 